JURNAL PENDIDIKAN

BIOLOGI INDONESIA

\begin{tabular}{|l|l|l|c|c|c|}
\hline JPI & Volume 5 & Number 2 & $\begin{array}{c}\text { Pages } \\
177-366\end{array}$ & $\begin{array}{c}\text { Malang } \\
\text { July 2019 }\end{array}$ & $\begin{array}{c}\text { ISSN: 2442-3750 (print) } \\
\text { ISSN: 2537-6204 (online) }\end{array}$ \\
\hline
\end{tabular}

Published by:

University of Muhammadiyah Malang, Indonesia

Collaborate with:

Asosiasi Lesson Study Indonesia (ALSI) 


\author{
ISSN: 2442-3750 (print) \\ ISSN: 2527-6204 (online) \\ Volume 5, Issue 2, July 2019
}

\begin{abstract}
Nationally Accredited based on the Decree of the Minister of Research, Technology and Higher Education of Indonesia, Number 30/E/KPT/2018 as a SINTA 2 journal.

JPBI (Jurnal Pendidikan Biologi Indonesia), ISSN 2442-3750 (print); ISSN 2527-6204 (online), publishes a scientific papers on the results of the study/research and review of the literature in the sphere of biology education in primary education, secondary education, and higher education. Additionally, this journal also covers the issues on environmental education. This journal collaborates with Asosiasi Lesson Study Indonesia (ALSI)/Indonesian Association of Lesson Study. Editor accepts the article has not been published in other media with the writing format as listed on page manuscript writing guidelines.

JPBI (Jurnal Pendidikan Biologi Indonesia) was established in 2015, published three times a year, on March, July, and November. Started by Volume 3, Number 3, November 2017, the journal was only published by using one language namely English. The journal has been indexed in DOAJ, BASE, Garuda, Google Scholar, SINTA, Asean Citation Index (ACI) and others.

JPBI (Jurnal Pendidikan Biologi Indonesia), in English is the "Indonesian Journal of Biology Education". The word "Indonesia" does not mean that the article is only written by an author from Indonesia, but it is more meaningful: (1) the journal publisher is from Indonesia and (2) the article needs to be related to conditions in Indonesia or countries that have the same conditions so that the article is expected to have implications and contributions to overcome Biology Education problems in Indonesia or possibilities to be applied in Indonesia.
\end{abstract}

\title{
Editorial Team
}

\section{Editor-in-Chief}

Dr. Atok Miftachul Hudha, Scopus ID: 57209580278; Department of Biology Education, University of Muhammadiyah Malang, East Java, Indonesia

\section{Section/Handling Editor}

1. Mr H. Husamah, Scopus ID: 57195803428 ; Department of Biology Education, University of Muhammadiyah Malang, East Java, Indonesia

2. Mrs Diani Fatmawati, Scopus ID: 57188975423; Department of Biology Education, University of Muhammadiyah Malang, East Java, Indonesia

3. Mr Ahmad Fauzi, Scopus ID: 57190423577 ; Department of Biology Education, University of Muhammadiyah Malang, East Java, Indonesia

\section{Editorial Advisory Regional Africa}

Prof. Dr. Anthony Kudjo Donkor, Scopus ID: 55794169000; University for Development Studies, Tamale, Ghana

\section{Editorial Advisory Regional America and Europe}

Assoc. Prof. Dr Siti N. Hidayati, Scopus ID: 6602160347; Department of Biology, Middle Tennessee State University, Murfreesboro, United States

\section{Editorial Advisory Regional South Asia}

Dr. Shahin Gavanji, Scopus ID: 54883969200; Chairman of World Academy of Medical Sciences (WAMS); Department of Biotechnology, Faculty of Advanced Sciences and Technologies, University of Isfahan, Isfahan, Iran, Islamic Republic of

\section{Editorial Advisory Regional Southeast Asia}

Prof. Dr. Henita Rahmayanti, Scopus ID: 57193697371, Department of Population and Environmental Education, Universitas Negeri Jakarta, The Special Capital of Jakarta, Indonesia

\section{Editorial Board}

- Prof. Dr. Nuryani Y Rustaman, Scopus ID: 55872695700; Science Education Departement, Indonesia University of Education (UPI), West Java, Indonesia

- Prof. Dr. Nobuyasu Katayama, Scopus ID: 7102706409; Tokyo Institute for Biology Education; and Department of Biology, Faculty of Education, Tokyo Gakugei University, Koganei, Japan, Japan

- Prof. Dr. Dongryeul Kim, Scopus ID: 57037347100, Biology Education Major, Department of Science Education, College of Education, Daegu National University of Education, Daegu, Korea, Republic of

- Prof. Dr. Animesh Ku. Mohapatra, Scopus ID: 35729036800; Department of Life Science, Regional Institute of Education (NCERT), Bhubaneswar, Odisha, India 
- Prof. Dr. Aloysius Duran Corebima, Scopus ID: 56857563800; Department of Biology, Universitas Kanjuruhan Malang, Malang, East Java; Prof. Emiritius at Universitas Negeri Malang, Indonesia

- Prof. Dr. Muhammad Faizal A. Ghani, Scopus ID: 49861280500; Department Of Educational Management, Planning, and Policy Faculty Of Education, University of Malaya, Kuala Lumpur, Malaysia

- Prof. Dr. Imran Parvez, Scopus ID: Hajee Mohammad Danesh Science and Technology University, Dinajpur, Bangladesh

- Assoc. Prof. Ziyn Engdasew, SCOPUS ID: 56006357200; School of Educational Sciences, Adama Science and Technology University, Ethiopia

- Assoc. Prof. Dr Siti N. Hidayati, Scopus ID: 6602160347; Department of Biology, Middle Tennessee State University, Murfreesboro, United States

- Assist. Prof. Dr Hidayah Binti Mohd Fadzil, Scopus ID: 56256057000; Department of Mathematics and Science Education, Faculty of Education, University of Malaya, Kuala Lumpur, Malaysia

- Assit. Prof. Pratchayapong Yasri, Scopus ID: 36543463100; Institute for Innovative Learning, Mahidol University, Nakhon Pathom, Thailand

- Assoc. Prof. Dr. Ruqiah Ganda Putri Panjaitan, Scopus ID: 55656556500, Biology Education Program, Mathematics and Natural Science Education Department, Teaching and Education Faculty, Universitas Tanjungpura, Indonesia

- Assoc. Prof. Dr Puguh Karyanto, Scopus ID: 57202219619, Department of Biology Education, Faculty of Teacher Training and Education, Universitas Sebelas Maret, Surakarta, Central Java; Head of Indonesian Consortioum for Biology Education, Indonesia

- Assoc. Prof. Dr. Agus Sutanto, Scopus ID: 57210971026; Department of Biology Education, University of Muhammadiyah Metro, Lampung, Indonesia

- Assoc. Prof. Dr. Yuni Pantiwati, Scopus ID: 57190660805, Biology Education, Postgraduate, Universitas Muhammadiyah Malang, Indonesia

- Assoc. Prof. Dr. Marheny Lukitasari, Scopus ID: 57201676274; Department of Biology Education, University of PGRI Madiun, East Java, Indonesia

- Mr IImi Zajuli Ichsan, Scopus ID: 57209737062; Department of Biology Education, Faculty of Mathematics and Sciences, Universitas Negeri Jakarta, Special Region of Jakarta, Indonesia

\title{
Copy Editor and Proofreader
}

- Assist. Prof. Tien Tien Lee, Ph.D; Scopus ID: 55220444400; Department of Chemistry; Faculty of Science \& Mathematics; Sultan Idris Education University, Malaysia

- Fuad Jaya Miharja, Scopus ID: 57208113299, Department of Biology Education, University of Muhammadiyah Malang, East Java, Indonesia

- Dwi Setyawan, Scopus ID: 57201433886, Department of Biology Education, University of Muhammadiyah Malang, East Java, Indonesia

- Dr Arsad Bahri, Scopus ID: 56857333400; Department of Biology, State University of Makassar (UNM), South Sulawesi, Indonesia

\section{Administration}

1. Tutut Indria Permana, Scopus ID: 56598093500; Department of Biology Education, University of Muhammadiyah Malang, East Java, Indonesia

2. Fendy Hardian Permana, Scopus ID; Department of Biology Education, University of Muhammadiyah Malang, East Java, Indonesia

3. Mr. Moh Mirza Nuryady, Scopus ID; 56809465100, Department of Biology Education, Universitas Muhammadiyah Malang, ID, Indonesia

\author{
Editorial Office \\ Department of Biology Education, Faculty of Teacher Training and Education, \\ University of Muhammadiyah Malang \\ 3rd Campus, 1st Floor, BioEdu Room, Tlogomas Street No. 246 Malang, East Java, Indonesia \\ Postal Code: 65144 \\ Phone: +62341- 464318 Ext.120 Fax: 0341- 460782 \\ E-mail: jpbi@umm.ac.id / journal.educationalbiology@gmail.com \\ Website: http://ejournal.umm.ac.id/index.php/jpbi
}




\section{TABLE OF CONTENT}

Improving students' motivation and collaborative skills through Remap Jigsaw learning combined with modelling activities Sri Endah Indriwati, Herawati Susilo, I Made Surya Hermawan

Moderated effect of teachers' attitudes to the contribution of technology competencies on TPACK

Hendra Yulisman, Ari Widodo, R. Riandi, Cut Intan Evtia Nurina

Ethnobotanical study of medicinal plants utilized by the Baduy tribe used as a learning resource

Rida Oktorida Khastini, Indria Wahyuni Wahyuni, Irma Saraswati, A. Alimuddin, Prasart Nuangchalerm

Complex Instruction Team Product (CITP) learning model: Improving student's scientific attitudes and learning outcomes

Dominggus Rumahlatu, Kristin Sangur, Sintje Liline .

The integration of PBL and cooperative script to empower critical thinking skills of biology students

Didimus Tanah Boleng, Elsje Theodora Maasawet

Naturalist intelligence and personality: An understanding students' responsible environmental behavior

Nina Wirdianti, Ratna Komala, Mieke Miarsyah

Environmental responsibility and pro-environmental behavior: Biology undergraduate students' profile

Diana Vivanti Sigit, Eka Putri Azrai, Erna Heryanti, Kasih Anggraeni, IImi Zajuli Ichsan, Rahmat Fadrikal.

Improving higher-order thinking skill through POE (Predict, Observe, Explain) and guided discovery learning models

Witriyani Suryamiati, Adi Pasah Kahar, Anandita Eka Setiadi .

Laboratory hands-on activity: A case study in senior high school of Pekanbaru-Indonesia

Maysi Hidayah Ramadhani, Prima Wahyu Titisari

Improving student learning outcomes in science subjects through the implementation of PBL-based module

Eva Nursa'ban, Mohammad Masykuri, Sri Yamtinah

Teaching science process skill using guided inquiry model with starter experiment approach: an experimental study

Ika Wardani, D. Djukri

Biology in the 21st-Century: Transformation in biology science and education in supporting the sustainable development goals

Yudha Gusti Wibowo, Ali Sadikin

A path analysis of the relation between study habit and students' academic achievement

Erik Prasetyo, Saiful Ridlo, Nugroho Edi Kartijono.

Augmented Reality for teaching science: Students' problem solving skill, motivation, and learning outcomes

Fitriana Nur Astuti, S. Suranto, Mohammad Masykuri.

Developing interactive questions to measure the higher-order thinking skills of senior high schools' students

A. Afandi, Saleh Hidayat, Indawan Syahri.

Thinking working scaffolding sharing model to improve natural science competencies for biology pre-service teachers

Avia Riza Dwi Kurnia, Muslimin Ibrahim, Wahono Widodo.

Diagnostic test assessment on protist misconception

Defita Raharjo, Murni Ramli, Yudi Rinanto

Environmental awareness and participation of Filipino pre-service teachers

Genalyn P. Lualhati

Cognitive Acceleration through Science Education (CASE) program: Accelerating students' cognitive development

Chandra Adi Prabowo, Wahyu Widodo.

Internship program: A viewpoint of pre-service teachers of Farhangian University-Shahid Beheshti branch of Tehran

Darioush Sharafie, Mohamadreza Ghorbani, Amin Dadashzadeh. 